\title{
Policy brief: Designing and implementing high-quality voluntary family planning programs
}

Population Council

Follow this and additional works at: https://knowledgecommons.popcouncil.org/departments_sbsr-rh

Part of the Demography, Population, and Ecology Commons, Family, Life Course, and Society Commons, International Public Health Commons, Maternal and Child Health Commons, Medicine and Health Commons, and the Women's Health Commons How does access to this work benefit you? Let us know!

\section{Recommended Citation}

"Policy brief: Designing and implementing high-quality voluntary family planning programs." New York: Population Council, 2012. 
DESIGNING AND

IMPLEMENTING

HIGH-QUALITY VOLUNTARY

FAMILY PLANNING

PROGRAMS

POPULATION COUNCIL

Ideas. Evidence. Impact. 
The Population Council confronts critical health and development issues-from stopping the spread of HIV to improving reproductive health and ensuring that young people lead full and productive lives. Through biomedical, social science, and public health research in 50 countries, we work with our partners to deliver solutions that lead to more effective policies, programs, and technologies that improve lives around the world. Established in 1952 and headquartered in New York, the Council is a nongovernmental, nonprofit organization governed by an international board of trustees.

\section{Population Council}

One Dag Hammarskjold Plaza

New York, NY 10017 USA

www.popcouncil.org

For more information, contact the Population Council's Office of Public Information: pubinfo@popcouncil.org | +1212-339-0509 


\section{INTRODUCTION}

Voluntary high-quality family planning programs reduce poverty, and improve women's and children's health, by speeding fertility declines. They are one of the most cost-effective health and development investments available to governments. On average, each dollar invested in family planning saves nearly two dollars in expenses related to antenatal, maternal, and newborn health care. If savings in other development sectors are taken into account as well, the return is even larger: Every dollar spent on family planning saves two to six dollars in interventions aimed at achieving other development goals. The largest benefits are seen in education and health sectors, with significant additional savings in water and sanitation, immunization, and malaria programs.

But, today, more than 200 million women worldwide lack access to modern contraception. If this unmet need for family planning could be met, 54 million unintended pregnancies, 26 million abortions, more than 79,000 maternal deaths, and 1.1 million infant deaths could be prevented each year. Families could save more and begin to break the grip of poverty. And communities could make greater investments in education, health care, and infrastructure.

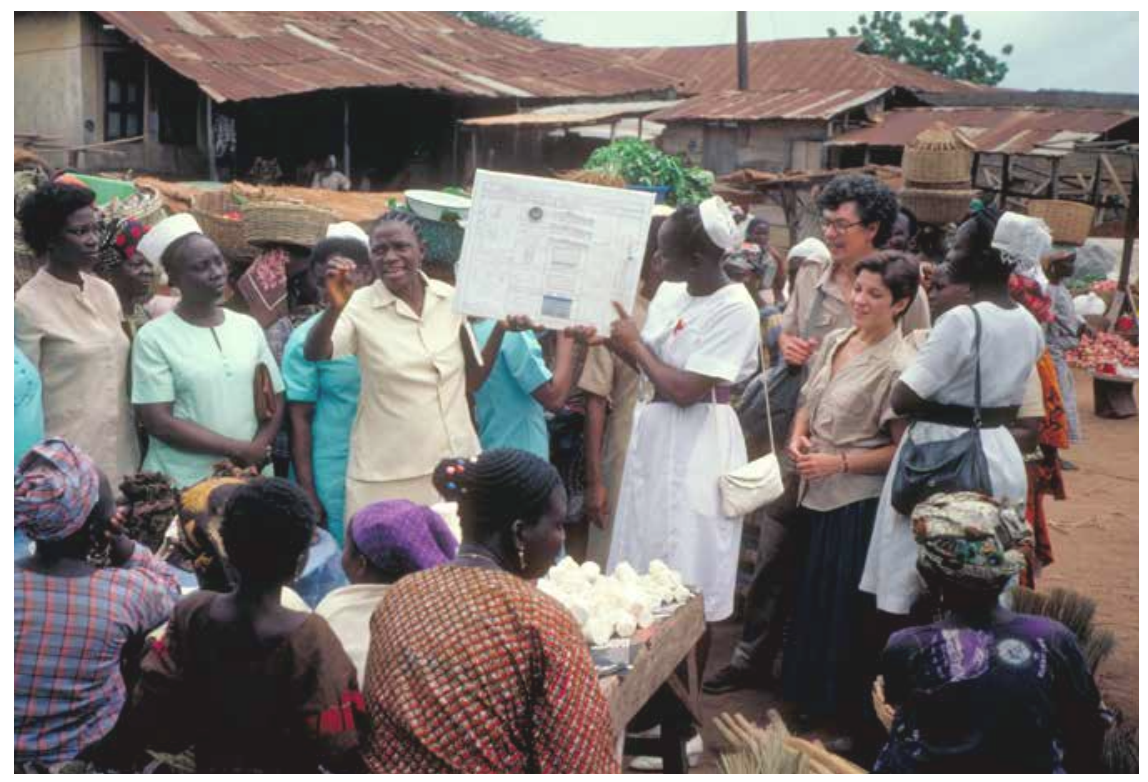

Health workers use a flip chart to discuss family planning at a market in Nigeria. 
Fortunately, global interest in family planning is growing as the benefits of family planning programs are becoming increasingly evident. International family planning conferences in 2009 in Kampala, Uganda, and in 2011 in Dakar, Senegal, drew unexpectedly large turnouts. And major donors such as the Bill \& Melinda Gates Foundation, the World Bank, and the UK Department for International Development have recently prioritized family planning. However, this revival has not yet resulted in widespread change in government policies or programs in the countries with the greatest need-those

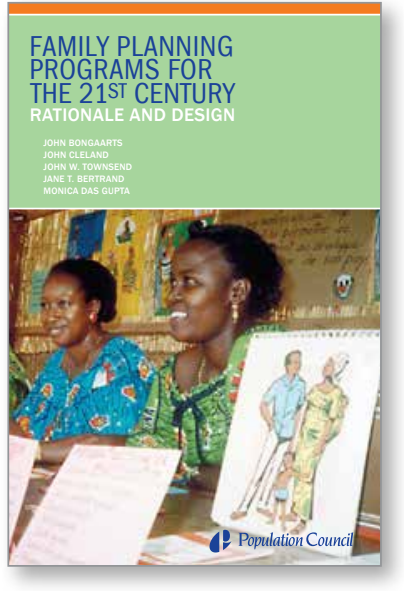
where high fertility and rapid population growth are jeopardizing public health and social and economic development.

A new Population Council book, Family Planning for the $21^{\text {st }}$ Century: Rationale and Design, provides a road map to help policymakers and donors of these priority countries implement high-quality family planning programs. The book explains the rationale for increased funding and support for voluntary family planning, and outlines how reinvigorated programs should be structured to operate most effectively.

\section{EVIDENCE: FAMILY PLANNING WORKS}

Voluntary family planning programs speed fertility declines, thus improving health and boosting the economy.

\section{IMPROVED HEALTH}

Effective contraception can significantly reduce maternal mortality in two ways. First, it can virtually eliminate maternal deaths due to unsafe abortion. Second, it can reduce the proportion of pregnancies that pose an aboveaverage risk to women's survival.

In addition, when women have access to family planning and are able to space their pregnancies at safe and appropriate intervals, they are healthier. Research shows that women who wait at least two years after giving birth before becoming pregnant again are more likely to avoid anemia and survive childbirth. 


\section{BENEFITS OF FAMILY PLANNING}

\section{HIGH-QUALITY FAMILY PLANNING PROGRAMS:}

\section{REDUCE}

$\rightarrow$ Fertility

$\rightarrow$ Abortion

$\rightarrow$ Maternal, infant, and child death

$\rightarrow$ Poverty

\section{IMPROVE}

$\rightarrow$ Maternal, infant, and child health

$\rightarrow$ Women's empowerment

$\rightarrow$ Economic growth

$\rightarrow$ Governmental ability to invest in schooling, health care, and infrastructure

\section{The longer a woman goes between pregnancies,}

\section{the lower the risk her child will die.}

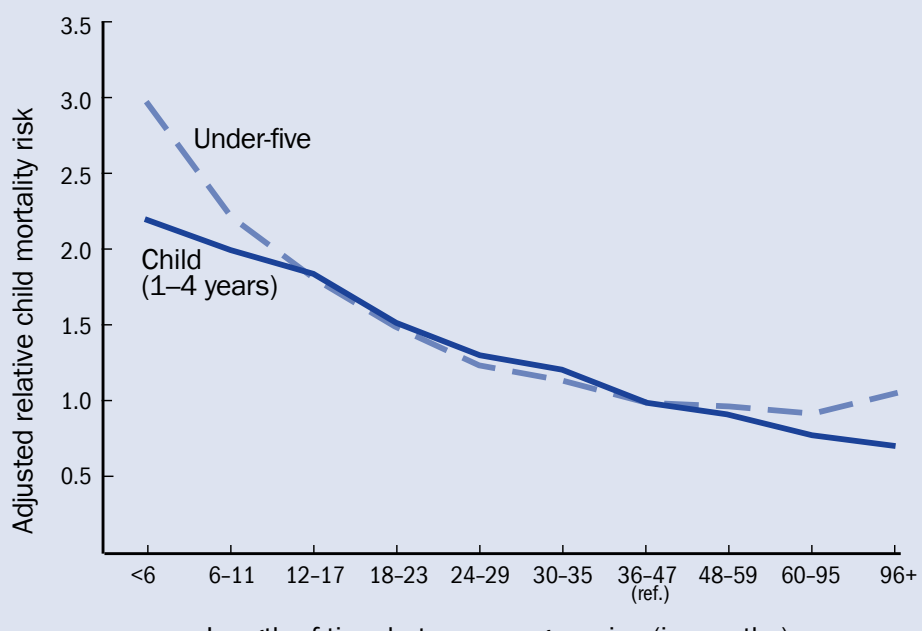

Length of time between pregnancies (in months)

Note: Under-five mortality = death at 0 to 59 months after birth; child mortality = death at 12 to 59 months after birth. Under-five mortality based on 1,049,196 births; child mortality based on 903,417 children. SOURCE: Rutstein (2008).

The length of time between births also has a powerful effect on children's health and survival. Children conceived within 24 months of an older sibling's birth are at greater risk of dying, even after controlling for other factors, such as poverty level, that could increase child mortality. The causes of the increased risk associated with short birth intervals may be related to maternal nutritional depletion from the previous pregnancy, sibling competition for food and other resources, and cross-infection from older siblings. 


\section{ECONOMIC IMPROVEMENTS}

Family planning programs reduce poverty and improve well-being:

- By reducing the birth rate, family planning programs can create a "demographic dividend" that boosts economic growth for a few decades by increasing the size of the labor force relative to both young and old dependents, and by making it possible for people to save money. About a third of the rapid economic growth rates experienced in recent decades by East Asian tiger economies is the result of this dividend.

- Slower population growth allows families and communities to invest more in providing quality education and health care and to improve infrastructure. Children who are healthy and educated are primed to become productive adults who can help fuel the economy.

- When families are able to plan and space their pregnancies, they can invest more in each family member. And women who have fewer children have more time to earn wages outside the home, which boosts family income and quality of life and reduces poverty.

When women have fewer children, the feasibility of pursuing nondomestic activities increases.

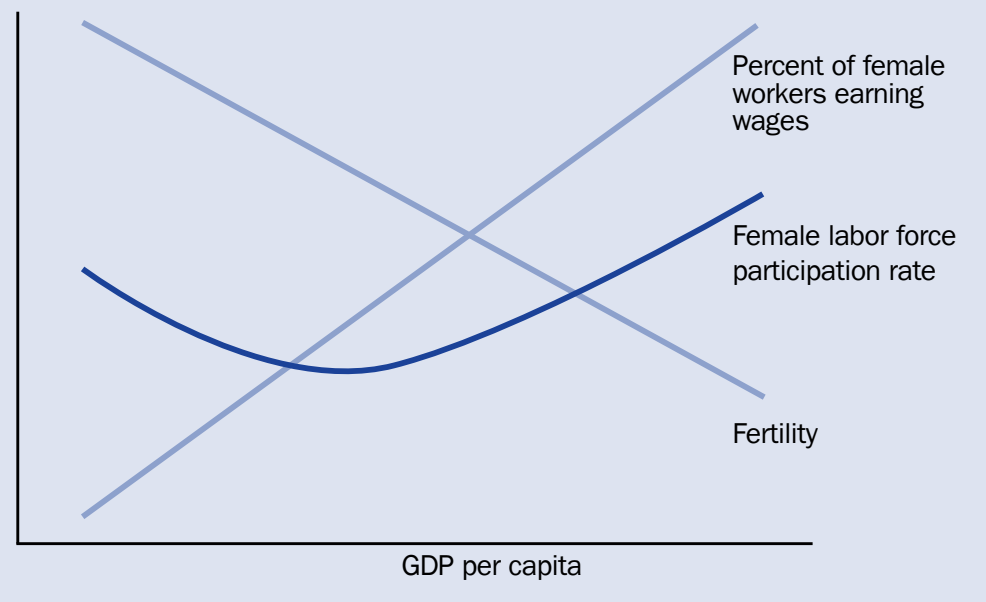

SOURCE: Adapted from Mammen and Paxton (2000). 
The health and socioeconomic benefits of family planning are the result of declines in childbearing. There is ample evidence that family planning programs effectively reduce fertility. This proof can be seen around the world in both controlled and "natural" experiments. One of the most compelling controlled experiments demonstrating the benefits of family planning is the landmark project undertaken in the Matlab district of Bangladesh. The Matlab population of 173,000 people was divided into two areas: a control area, which received the standard set of health-care services that were available countrywide, and an experimental area, where access to services was greatly expanded to include home visits, a wide array of contraceptive choices, and follow-up care. The impact in the experimental area was large and immediate: contraceptive use increased markedly and fertility declined rapidly. The program was expanded nationwide, contributing to a rapid fertility decline in Bangladesh.

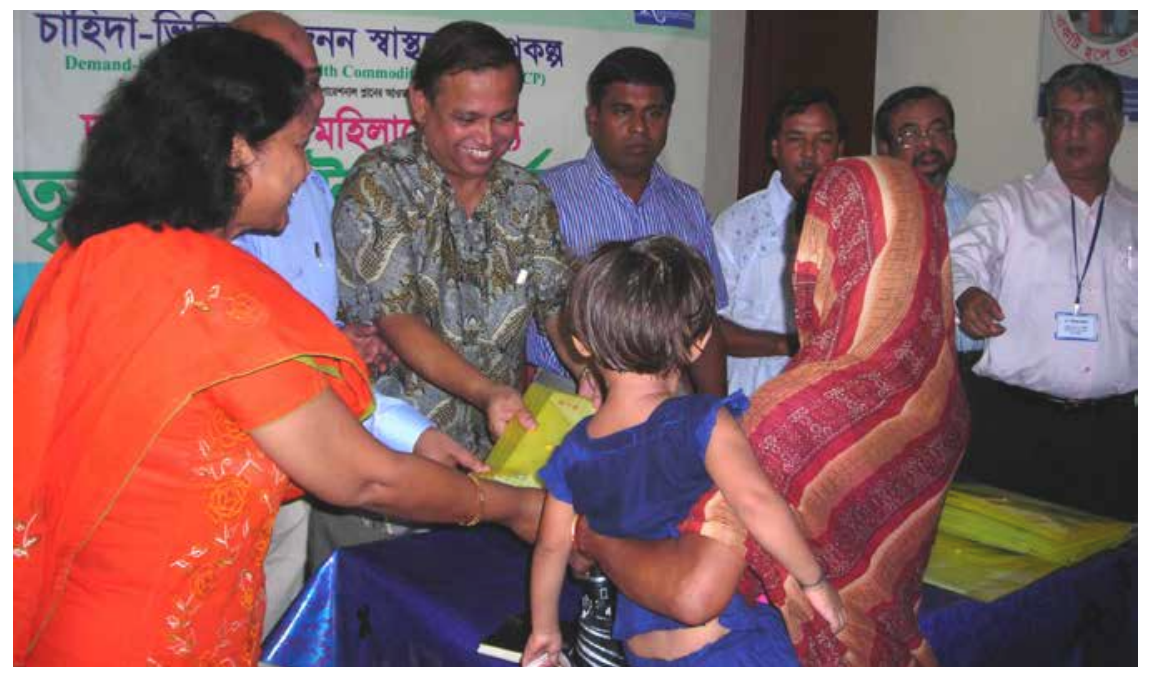

A Bangladeshi woman receives information about maternal health and family planning services.

There are several examples of natural experiments in which a country that invested in a strong voluntary family planning program experienced significantly greater fertility decline-and an improvement in the economy, public health, and the standard of living-than a country that did not. The differences are evident when one examines the following countries: Jordan vs. Iran; Uganda vs. Kenya; Pakistan vs. Bangladesh, and Burundi vs. Rwanda (see pages 6 and 7). 


\section{FAMILY PLANNING PROGRAMS EFFECTIVELY REDUCE FERTILITY: FOUR CASE STUDIES}

In 1989 the Iranian government became a strong supporter of family planning. The response was immediate and large. Fertility declined from more than 5 births per woman in the late 1980 s to around 2 in 2000; it remained greater than 3.5 in Jordan.

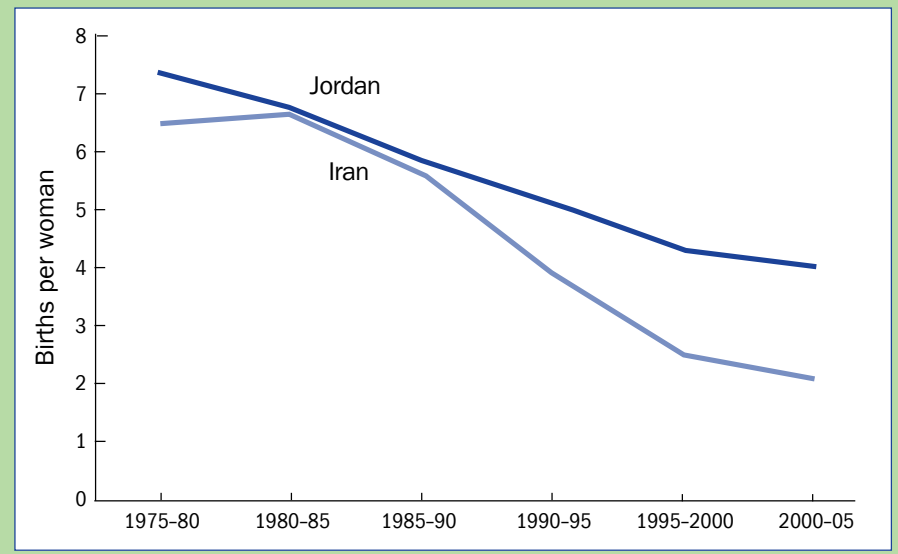

SOURCE: UN (2009).

Uganda's government has made very little investment in family planning. In contrast, Kenya in the 1960s was one of the first countries in Africa to develop a population policy and establish a family planning program.

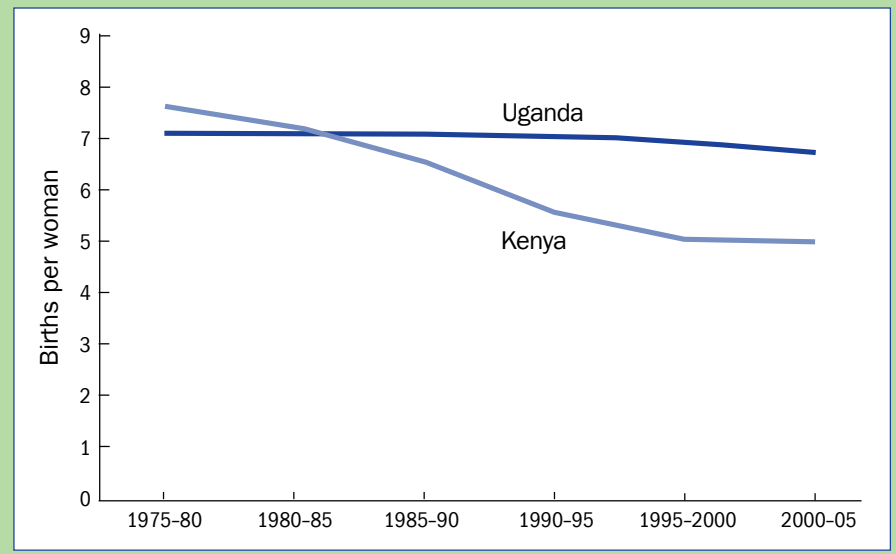

SOURCE: UN (2009). 
Bangladesh has implemented one of the world's most effective voluntary family planning programs. Historically, Pakistan's program has lacked government funds and commitment. However, Pakistan has indicated it may increase its investment in family planning with support from development partners, following the completion of the Population Council's FALAH project, which increased contraceptive use by an average of 28 percent in conservative districts of the country in less than four years.

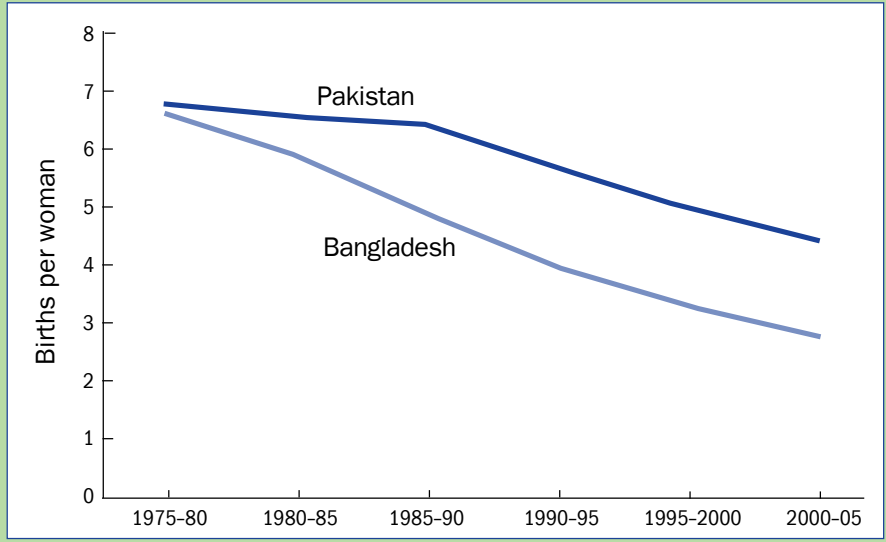

SOURCE: UN (2009).

Over the past decade the Rwandan government has made large new investments in health and family planning (with strong support from international donors). As a result, Rwanda's fertility has dropped from 6.1 births per woman in 2005 to 4.6 births per woman in 2010. In Burundi, fertility remains at 6.4 births per woman.

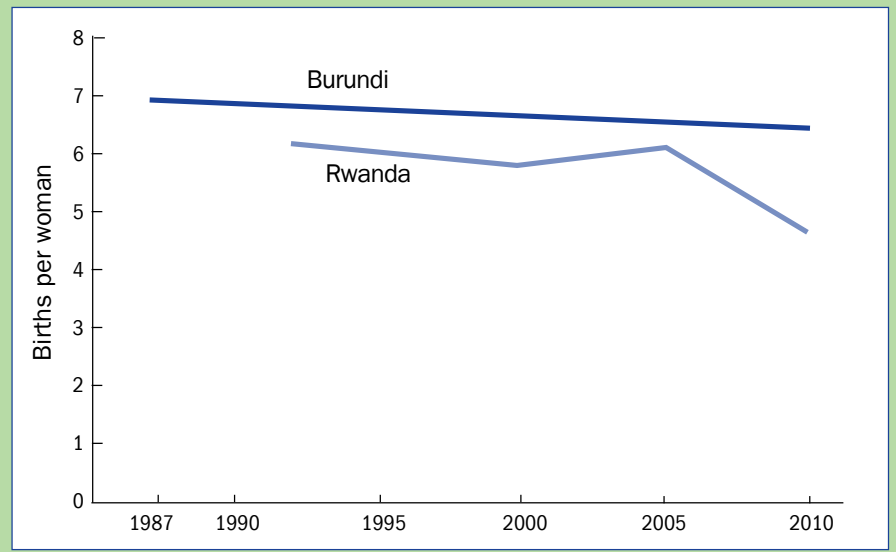

SOURCE: UN (2009). 


\section{BEST PRACTICES}

For voluntary family planning programs to have the greatest impact, they must be implemented well. In countries with high fertility and rapid population growth-where contraceptive use is still uncommon and attitudes can range from ambivalent to hostile-strong government funding and support is essential to achieving rapid gains in contraceptive prevalence.

Evidence shows that the most effective strategy for family planning services is offering clients easy access to a wide range of affordable contraceptive methods through multiple service delivery channels in a good-quality, reliable fashion. In the past 50 years, policymakers and program managers have learned a great deal about how to do this. The best practices on the back of this policy brief are recommended for the implementation of effective, costeffective, equitable, and high-quality voluntary family planning services.

\section{IN SUM}

Family planning is one of the most successful development interventions of the past 50 years. It is unique in its range of potential benefits, encompassing economic development, maternal and child health, educational advances, and women's empowerment. Research shows that with high-quality voluntary family planning programs, governments hold the power to reduce fertility and generate substantial improvements in health, wealth, human rights, and education. 
The Power of Family Planning: <http://www.popcouncil.org/familyplanning >

"Family planning: A key to prosperity," essay by Population Council Distinguished Scholar John Bongaarts: <http://www.popcouncil.org/ar2011/familyplanning.html >

"A Mother's Day gift," essay about family planning by Population Council president

Peter J. Donaldson: < http://www.huffingtonpost.com/peter-j-donaldson/

family-planning_b_1500528.html >

Adding It Up: Costs and Benefits of Contraceptive Services-Estimates for 2012, a Guttmacher Institute report on the benefits of investing in family planning and maternal and newborn health: <http://www.guttmacher.org/pubs/AlU-2012-estimates.pdf >

Guttmacher Institute fact sheet on investing in family planning and maternal and newborn health (2012): <http://www.guttmacher.org/pubs/FB-Costs-Benefits-Contraceptives.pdf >

Reproductive Health Supplies Coalition: <http://www.rhsupplies.org >

The coalition hosts a website to disseminate information about the sources, shipment, and costs of contraceptive products. The website provides up-to-date, standardized data on shipments of contraceptive supplies to more than 140 countries.

WHO's Essential Drug List: <http://www.who.int/medicines/publications/ essentialmedicines/en/>

Reproductive Health Vouchers: <http://www.rhvouchers.org/>

\section{PUBLICATIONS}

Bongaarts, John, John Cleland, John W. Townsend, Jane T. Bertrand, and Monica Das Gupta. 2012. Family Planning for the 21st Century: Rationale and Design. New York: Population Council. <http://www.popcouncil.org/pdfs/2012_FPfor21stCentury.pdf >

Bongaarts, John and Steven Sinding. 2011. "Family planning as an economic investment," SAIS Review of International Affairs, D31(2): 35-44.

Kohler, Hans-Peter. 2012. “Copenhagen Consensus 2012: Challenge Paper on 'Population Growth."” PSC Working Paper Series, PSC 12-03.

Moreland, Scott and Sandra Talbird. 2006. Achieving the Millennium Development Goals: The contribution of fulfilling the unmet need for family planning. Washington, DC: USAID.

Schultz, T. Paul. 2009. "The gender and intergenerational consequences of the demographic dividend: An assessment of the micro- and macro linkages between the demographic transition and economic development," The World Bank Review Economic Review 23(3): 427-442.

Singh, Susheela and Jacqueline E. Darroch. 2012. Adding It Up: Costs and Benefits of Contraceptive Services-Estimates for 2012. New York: Guttmacher Institute and United Nations Population Fund (UNFPA).

United Nations Commission on Population and Development. 2009. Flow of Financial Resources for Assisting in the Implementation of the Programme of Action of the International Conference on Population and Development. Report of the Secretary-General (E/CN.9/2009/5).

United Nations, Department of Economic and Social Affairs. 2009. "What would it take to accelerate fertility decline in the least developed countries?" UN Population Division Policy Brief No. 2009/1.

UN Millennium Project. 2006. Public Choices, Private Decisions: Sexual and Reproductive Health and the Millennium Development Goals. New York: United Nations Development Programme. 


\section{BEST PRACTICES FOR IMPLEMENTING VOLUNTARY FAMILY PLANNING PROGRAMS}

\begin{tabular}{|c|c|}
\hline RECOMMENDATION & RATIONALE \\
\hline $\begin{array}{l}\text { Integrate voluntary } \\
\text { family planning } \\
\text { programs into existing } \\
\text { health systems. }\end{array}$ & $\begin{array}{l}\text { Program managers will reach more of their core } \\
\text { clients if they integrate family planning services } \\
\text { with other health and reproductive health services, } \\
\text { especially antenatal and postnatal care and } \\
\text { immunization. }\end{array}$ \\
\hline $\begin{array}{l}\text { Find novel ways to } \\
\text { reach the poorest } \\
\text { and most vulnerable } \\
\text { with voluntary family } \\
\text { planning programs. }\end{array}$ & $\begin{array}{l}\text { Policymakers should consider offering generic } \\
\text { products and other innovative strategies to ensure } \\
\text { that hormonal contraception is available to users at } \\
\text { the lowest prices. }\end{array}$ \\
\hline $\begin{array}{l}\text { Provide voluntary family } \\
\text { planning in ways that } \\
\text { are flexible, feasible, and } \\
\text { acceptable to the local } \\
\text { community. }\end{array}$ & $\begin{array}{l}\text { Beyond hospitals, public clinics, and private } \\
\text { physicians, other delivery systems include newer } \\
\text { forms of community-based distribution, social } \\
\text { marketing, social franchises, and reproductive health } \\
\text { vouchers. }\end{array}$ \\
\hline $\begin{array}{l}\text { Use evidence to } \\
\text { shape the design and } \\
\text { evaluation of voluntary } \\
\text { family planning } \\
\text { programs. }\end{array}$ & $\begin{array}{l}\text { Effective programs draw heavily on evidence-based } \\
\text { research and evaluation. Program planners should } \\
\text { use research and evaluation-from formative research } \\
\text { to situation analysis and operations research-in } \\
\text { the initial design, as well as to make mid-course } \\
\text { corrections. }\end{array}$ \\
\hline $\begin{array}{l}\text { Ensure a consistent } \\
\text { supply of modern } \\
\text { contraceptives. }\end{array}$ & $\begin{array}{l}\text { WHO's Essential Drug List facilitates decisions about } \\
\text { what products are appropriate for a given setting } \\
\text { and provider skill level. Governments can look to } \\
\text { the Reproductive Health Supplies Coalition, which } \\
\text { collaborates with donors, procurement agencies, } \\
\text { manufacturers, and other organizations to improve } \\
\text { procurement capacity and strengthen logistic } \\
\text { management systems. }\end{array}$ \\
\hline $\begin{array}{l}\text { Give voluntary family } \\
\text { planning programs } \\
\text { adequate funding. }\end{array}$ & $\begin{array}{l}\text { The costs of family planning services are modest, } \\
\text { and the benefits large, relative to other public health } \\
\text { interventions. }\end{array}$ \\
\hline $\begin{array}{l}\text { Create strong, } \\
\text { culturally relevant } \\
\text { communications } \\
\text { programs for voluntary } \\
\text { family planning } \\
\text { programs. }\end{array}$ & $\begin{array}{l}\text { Family planning programs must build in a robust } \\
\text { communications component to convey the benefits } \\
\text { of contraception and motivate people to adopt family } \\
\text { planning when they would like to avoid pregnancy. } \\
\text { They should also take advantage of new and evolving } \\
\text { information technologies that will allow them to } \\
\text { achieve even more with each coming generation. }\end{array}$ \\
\hline
\end{tabular}

